\title{
Effect of Positive Surgical Margin on Survival After Partial Nephrectomy for Renal Cell Cancer: Long-term Results of a Single Center
}

\author{
Böbrek Hücreli Kanserlerde Parsiyel Nefrektomi Sonrası Pozitif Cerrahi Sınırın Sağkalıma \\ Etkisi: Tek Merkezin Uzun Dönem Sonuçları
}

\author{
(D) Mehmet Çağlar Çakıcı ${ }^{1}$, (D) Nihat Karakoyunlu², (D) Alihan Kokurcan², (D) Sercan Sarı, (D) Fatih Sandıkçı², \\ (D) 0sman Raif Karabacak2, (D) Levent Sağnak², (D) Hikmet Topaloğlu2 , (D) Hamit Ersoy² \\ 1 İstanbul Medeniyet University, Göztepe Training and Research Hospital, Clinic of Urology, İstanbul, Turkiye \\ 2University of Health Sciences Turkiye, Dışkapı Yıldırım Beyazıt Training and Research Hospital, Clinic of Urology, Ankara, Turkiye \\ ${ }^{3}$ Bozok University Faculty of Medicine Hospital, Department of Urology, Yozgat, Turkiye
}

\section{What's known on the subject? and What does the study add?}

It is known that the clinical and oncological effects of positive surgical margins (PSM) after partial nephrectomy (PN) have been addressed previously. In recent years, studies which showed that PSM does not have oncologically worse effects have increased. However, data regarding long-term results of PSM is scarce. Results of our study indicated that PSM after PN does not have clinically and oncologically worse effects in long-term follow-up.

\begin{abstract}
Objective: The goal of this study is to evaluate the risk factors that cause positive surgical margin (PSM) after partial nephrectomy (PN) and the effect of PSM on oncological outcomes in a single-centre cohort.

Materials and Methods: Patients with PSM (group 1) were identified and contrasted with the negative surgical margin (group 2). Further, the Kaplan-Meier curves and Cox regression models were used to estimate the differences in survival analysis.

Results: A total of 302 patients had PN, of which 38 (12.6\%) had PSM. In addition, the non-ischaemic procedures in group 1 were higher ( $<<0.001$ ). Multivariate analysis showed that RENAL nephrometry score (OR: 1.438, $p=0.037)$ and C-index value (OR: $0.224, p=0.012)$ were important predictive factors for PSM. Moreover, the recurrence rate was 7.9\% for group 1 at a median follow-up of 85.2 months and $3.4 \%$ for group 2 at a median follow-up of 83.7 months $(p=0.181)$. In a multivariate analysis, the overall survival decreased with co-morbidity index (HR: $1.343, p<0.001)$ and high tumour stage (HR: 3.886, $p=0.003)$, while cancer-specific survival decreased with mid-renal tumours (HR: 4.157, $p=0.007)$, high tumour stage (HR: $6.274, p=0.017$ ) and recurrence (HR: 5.038, $p=0.018$ ). Furthermore, pathological T stage and $\mathrm{C}$-index value were independent risk factors influencing recurrence-free survival.

Conclusion: C-index and RENAL nephrometry score are independent risk factors for PSM. Additionally, PSM does not affect the recurrence or survival outcomes.
\end{abstract}

Keywords: Partial nephrectomy, Positive surgical margin, Survival

\section{Öz}

Amaç: Parsiyel nefrektomi (PN) sonrası pozitif cerrahi sınıra (PSM) neden olan risk faktörlerini ve PSM'nin onkolojik sonuçlar üzerindeki etkisini tek merkezli bir kohortta değerlendirmek.

Gereç ve Yöntem: PSM'li hastalar (grup 1) belirlendikten sonra negatif cerrahi sınırlı (grup 2) hastalar ile karşılaştırıldı. Kaplan-Meier eğrileri ve Cox-regresyon modelleri, sağkalım analizindeki farkıııkları tahmin etmek için kullanıldı.

Correspondence: Mehmet Çağlar Çakıcı MD, İstanbul Medeniyet University, Göztepe Training and Research Hospital, Clinic of Urology, İstanbul, Turkiye Phone: +90 5376102438 E-mail: mcaglarcakici@hotmail.com ORCID-ID: orcid.org/0000-0002-0176-5887

Received: 14.09 .2020 Accepted: 24.11 .2020

Cite this article as: Çakıcı MÇ, Karakoyunlu N, Kokurcan A, Sarı S, Sandıkçı F, Karabacak OR, Sağnak L, Topaloğlu H, Ersoy H. Effect of Positive Surgical Margin on Survival After Partial Nephrectomy for Renal Cell Cancer: Long-term Results of a Single Centre. Journal of Urological Surgery, 2020;7(4):316-324

๑Copyright 2020 by the Association of Urological Surgery / Journal of Urological Surgery published by Galenos Publishing House. 
Bulgular: Toplam 302 hastaya PN yapıldı ve bunların 38'inde $(\% 12,6)$ PSM vardı. Grup 1'de iskemik olmayan operasyonlar daha fazlaydı (p<0,001). Çok değişkenli analiz, RENAL nefrometri skorunun (OR: 1,438, p=0,037) ve C-indeksi değerinin $(0 R$ : $0,224, p=0,012)$ PSM için önemli prediktif faktörler olduğunu gösterdi. Nüks oranı, 85,2 aylık medyan takip süresinde grup 1'de \%7,9 ve 83,7 aylık medyan takip süresinde grup 2'de \%3,4 idi $(p=0,181)$. Çok değişkenli analizde genel sağkalım; komorbidite indeksi (HR: 1,343, p<0,001) ve yüksek tümör evresi $(H R: 3,886, p=0,003)$ ile azalırken kansere özgü sağkalım; orta zon tümörler (HR: 4,157, p=0,007), yüksek tümör evresi (HR: 6,274, p=0,017) ve nüks $(H R$ : $5,038, p=0,018)$ ile azaldı. Patolojik-T evresi (HR: 32,956, p<0,001) ve C-indeksi değeri (HR: 0,352, p=0,045) rekürrenssiz sağkalımı etkileyen bağımsız risk faktörleriydi.

Sonuç: RENAL nefrometri skoru ve C-indeksi değeri PSM için bağımsız risk faktörüdür. Çalışmamızdaki veriler, PSM'nin rekürrens veya sağkalım sonuçlarını etkilemediğini göstermektedir.

Anahtar Kelimeler: Parsiyel nefrektomi, Pozitif cerrahi sınır, Sağkalım

\section{Introduction}

The percentage of incidental renal mass detection has increased due to the increasing frequency of diagnostic imaging methods. Nephron-sparing surgery is currently recommended for patients with organ-confined renal cell cancer (RCC). In this way, the protection of kidney functions is prioritised. Partial nephrectomy $(\mathrm{PN})$ is the preferred treatment for organ-confined renal masses with equivalent oncological and superior functional outcomes compared to radical nephrectomy $(1,2)$. As a result of the advancement of technology and growing clinical knowledge, PN may be involved in more challenging cases.

As a result of insufficient tumour resection or persistent microscopic tumour extension, which may increase in difficult cases, positive surgical margins (PSM) appear in the histopathological evaluation (3-5). However, several studies concluded that the survival of PSM patients was not worse (36). In certain studies, local recurrence was reported as a result of aggressive tumours, and course of the disease could be worse. These patients had high-stage tumours with higher Fuhrman grade at the time of diagnosis $(3,7)$.

The aim of the current study was to evaluate the oncological effects of microscopic PSM in histopathology of patients who underwent PN for clinically localised RCC and disease management.

\section{Materials and Methods}

Following the approval by the local ethics committee (approval date: 20.01.2020, decision number: 80/08), the records of patients who underwent PN for renal mass between 2006 and 2018 were reviewed retrospectively. Furthermore, this study was a retrospective analysis of the database, covering all clinical, surgical, oncological and follow-up data for more than 400 consecutive patients who underwent open or laparoscopic PN in our clinic. Demographic data, peri-operative characteristics and histopathological and follow-up outcomes of patients were recorded. Computed tomography (CT) and/or magnetic resonance imaging (MRI) were used for pre-operative renal and tumour imaging, and thoracic X-ray or $\mathrm{CT}$ data were recorded.
Tumour size, localisation, clinical stage, surgical method and approach preferences were also recorded. All renal scoring systems were calculated by the same urologist. Additionally, tumour size was measured as the longest diameter of the tumour. Procedures were carried out by a team of four experienced surgeons with at least 10 years of urooncological experience. In the event of suspicion of macroscopic PSM, the resection was extended to the parenchyma and the procedure was completed. Histopathological assessments were conducted by a pathologist with 18 years of experience. Moreover, microscopic PSM was identified as the entity of cancer cells on the inked surface of the specimen.

Peri-operative complications were evaluated according to the modified Clavien-Dindo classification (8). Tumour subtype, Fuhrman nuclear grade (9), pathological stage and other histopathological features were also recorded. Hence, the clinical follow-up scheme after PN consisted of clinical visits every 3 months for the first year. In addition, all patients were examined at regular periods following PN with serum creatinine, liver function tests and thoracic and abdominal contrastenhanced CT or MRI at 6 months post-operatively and every 1224 months thereafter. In PSM patients, in addition to standard cross-sectional imaging, ultrasonography was performed every 6 months for the first 3 years and active surveillance was performed. Patient data were also collected from follow-up cards that were filled in at each admission and from patient interviews. Masses with benign pathology $(n=46)$, non-RCC malignant masses $(n=11)$ and patients with missing data $(n=77)$ were excluded from this study. As a result of histopathological evaluation, patients with PSM (group 1) and patients with negative surgical margin (NSM) (group 2) were compared.

\section{Statistical Analysis}

One-sample Kolmogorov-Smirnov test was used to verify if the data displayed a normal distribution for numerical variables. Mean \pm standard deviation was found in the data with normal distribution, and median interquartile range (IQR) values were recorded in the data with no normal distribution. Numerical variables were compared to the Student's t-test when parametric test criteria were found. In the absence of such criteria, Mann- 
Whitney U test was used. Moreover, two proportion z-tests, Pearson's chi-squared test and Fisher's Exact test were used to evaluate if there was a discrepancy between the percentages of categorical variables. Binary logistic regression analysis was used to obtain independent risk factors relevant to PSM. KaplanMeier survival curves with a 95\% confidence interval (CI) were used to assess the effect of surgical margin status on overall survival (OS), cancer-specific survival (CSS) and recurrence-free survival (RFS) after PN. The logrank test was used to compare survival results between PSM and NSM patients. In addition, multivariate Cox regression analysis was used for variables that were statistically significant in the univariate analysis and used to evaluate the factors influencing survival, and $\mathrm{Cl}$ was given with hazard ratio. For all tests, the probability of first type error was $\alpha=0.05$. Statistical analysis of the study was carried out using IBM SPSS 22.0 package programme.

\section{Results}

A total of 302 patients who underwent PN due to RCC were analysed in our clinic. PSM was observed in $38(12.6 \%)$ patients. No macroscopic PSMs or residual tissues were present in all cohorts. Cases with PSM were specified as a microscopic entity in the parenchymal resection margin. There was no difference in demographic characteristics between the two groups. The tumour size measured by radiological imaging was $38.6 \pm 15.2$ $\mathrm{mm}$ in group 1 and $39.0 \pm 17.4 \mathrm{~mm}$ in group 2. The Padua score was $8.3 \pm 2.2$, and the $\mathrm{C}$-index value was $1.8 \pm 0.5$ in group 1 and $8.3 \pm 1.6$ and $2.1 \pm 0.9$ in group $2(p=0.922$ and $p=0.016$, respectively). Open PN patients were 76.3\% in group 1 and $67.8 \%$ in group 2. Retroperitoneal approach was favoured in the majority of patients and $65.8 \%$ and $75.8 \%$, respectively, in groups 1 and $2(p=0.187)$. Non-ischaemic procedures were the majority in group 1 with a rate of $60.5 \%(p<0.001)$. Histopathological outcomes in both groups were not statistically different. Perioperative complications in both groups were frequently low grade $(p=0.249$ ) (Table 1$)$.

Multivariate binary logistic regression analysis model adjusting for covariates stated by univariate analysis showed that RENAL nephrometry score (OR: $1.438,95 \% \mathrm{Cl}: 1.202-1.850, p=0.037$ ) and $\mathrm{C}$-index value (OR: $0.224,95 \% \mathrm{Cl}: 0.070-0.723, \mathrm{p}=0.012$ ) were significant predictive factors for PSM. The median followup period was 85.2 (IOR, 10.1-160.4) months in group 1 and 83.7 $(I Q R, 13.5-153.9)$ months in group $2(p=0.869)$. Three patients (7.9\%) in group 1 and nine (3.4\%) in group 2 underwent radical nephrectomy due to local or systemic recurrence at a median period of 28.2 months from PN ( $p=0.181)$. The remaining 35 patients in group 1 underwent intensive surveillance. Three (7.9\%) patients in group 1 and 14 (5.3\%) in group 2 died of cancer-related condition (Table 2). Furthermore, the 5-, 10- and

\begin{tabular}{|c|c|c|c|}
\hline & $\begin{array}{l}\text { Group } 1 \\
(n=38)\end{array}$ & $\begin{array}{l}\text { Group } 2 \\
(\mathrm{n}=264)\end{array}$ & p-value \\
\hline Age (years), mean $\pm S D$ & $58.1 \pm 9.6$ & $56.2 \pm 12.2$ & 0.350 \\
\hline \multicolumn{4}{|l|}{ Gender, n (\%) } \\
\hline Male & $22(57.9)$ & $165(62.5)$ & \multirow[t]{2}{*}{0.585} \\
\hline Female & $16(42.1)$ & $99(37.5)$ & \\
\hline $\begin{array}{l}\text { Body mass index }, \mathrm{kg} / \mathrm{m}^{2} \\
\text { mean } \pm \mathrm{SD}\end{array}$ & $28.1 \pm 3.4$ & $27.3 \pm 4.3$ & 0.270 \\
\hline $\begin{array}{l}\text { Charlson co-morbidity } \\
\text { index, mean } \pm \text { SD }\end{array}$ & $2.8 \pm 1.9$ & $3.5 \pm 2.2$ & 0.902 \\
\hline $\begin{array}{l}\text { Incidentally detected, } \mathrm{n} \\
(\%)\end{array}$ & $18(47.4)$ & $136(51.5)$ & 0.633 \\
\hline \multicolumn{4}{|c|}{ ECOG Performance Score, n (\%) } \\
\hline $0-1$ & 32 (84.2) & $230(87.1)$ & \multirow[t]{2}{*}{0.621} \\
\hline $2-3$ & $6(15.8)$ & $34(12.9)$ & \\
\hline \multicolumn{4}{|l|}{ ASA score, $\mathrm{n}(\%)$} \\
\hline $1-2$ & $25(65.8)$ & $196(74.2)$ & \multirow[t]{2}{*}{0.271} \\
\hline $3-4$ & $13(34.2)$ & $68(25.8)$ & \\
\hline $\begin{array}{l}\text { Tumor size, mm; mean } \pm \\
\text { SD }\end{array}$ & $38.6 \pm 15.2$ & $39.0 \pm 17.4$ & 0.897 \\
\hline Polar position, $\mathrm{n}(\%)$ & $26(68.4)$ & $164(62.1)$ & 0.452 \\
\hline $\begin{array}{l}\text { Renal Nephrometry score, } \\
\text { mean } \pm \text { SD }\end{array}$ & $6.8 \pm 1.9$ & $6.7 \pm 1.6$ & 0.598 \\
\hline PADUA score, mean \pm SD & $8.3 \pm 2.2$ & $8.3 \pm 1.6$ & 0.922 \\
\hline C-index, mean \pm SD & $1.8 \pm 0.5$ & $2.1 \pm 0.9$ & 0.016 \\
\hline \multicolumn{4}{|l|}{ Clinical T stage, n (\%) } \\
\hline T1a & $23(60.5)$ & $162(61.4)$ & \multirow[t]{5}{*}{0.478} \\
\hline T1b & $15(39.5)$ & $90(34.1)$ & \\
\hline T2a & - & $8(3.0)$ & \\
\hline $\mathrm{T} 2 \mathrm{~b}$ & - & $3(1.1)$ & \\
\hline T3a & - & $1(0.4)$ & \\
\hline \multicolumn{4}{|l|}{ Histotype of RCC, n (\%) } \\
\hline Clear cell & $31(81.6)$ & $185(70.1)$ & \multirow[t]{4}{*}{0.184} \\
\hline Papillary & $3(7.9)$ & $50(18.9)$ & \\
\hline Chromophobe & $4(10.5)$ & $24(9.1)$ & \\
\hline Other & - & $5(1.9)$ & \\
\hline \multicolumn{4}{|l|}{ Nuclear grade, n (\%) } \\
\hline Grade I-II & $31(81.6)$ & $197(74.6)$ & \multirow[t]{3}{*}{0.121} \\
\hline Grade III-IV & $2(5.3)$ & $43(16.3)$ & \\
\hline N/A & 5 (13.2) & $24(9.1)$ & \\
\hline \multicolumn{4}{|c|}{ Pathological TNM stage, $\mathrm{n}(\%)$} \\
\hline Stage I & 37 (97.4) & $246(93.2)$ & \multirow[t]{4}{*}{0.389} \\
\hline Stage II & - & $10(3.8)$ & \\
\hline Stage III & $1(2.6)$ & $7(2.7)$ & \\
\hline Stage IV & - & $1(0.4)$ & \\
\hline Presence of necrosis, $\mathrm{n}(\%)$ & $6(15.8)$ & $21(8.0)$ & 0.114 \\
\hline \multicolumn{4}{|l|}{ Surgery technique, n (\%) } \\
\hline Open & $29(76.3)$ & $179(67.8)$ & \multirow[t]{3}{*}{0.289} \\
\hline Laparoscopically & $9(23.7)$ & $70(26.5)$ & \\
\hline Laparoscopically $\rightarrow$ Open & - & $15(5.7)$ & \\
\hline Presence of ischemia, $\mathrm{n}(\%)$ & $15(39.5)$ & $181(68.8)$ & $<0.001$ \\
\hline $\begin{array}{l}\text { Operation time, min; mean } \\
\pm \text { SD }\end{array}$ & $122.1 \pm 41.2$ & $118.6 \pm 30.9$ & 0.537 \\
\hline
\end{tabular}




\begin{tabular}{|l|l|l|l|}
\hline \multicolumn{4}{|l|}{ Table 1 continuation } \\
\hline $\begin{array}{l}\text { Amount of bleeding, } \mathrm{mL} ; \\
\text { mean } \pm \text { SD }\end{array}$ & $331.6 \pm 169.4$ & $343.3 \pm 229.0$ & 0.762 \\
\hline $\begin{array}{l}\text { Duration of hospital stay, } \\
\text { day; mean } \pm \text { SD }\end{array}$ & $4.7 \pm 1.3$ & $4.7 \pm 2.0$ & 0.878 \\
\hline Complication, $\mathrm{n}(\%)$ & $25(65.8)$ & $197(74.6)$ & 0.249 \\
\hline Clavien-Dindo score 0-1 & $13(34.2)$ & $67(25.4)$ & \\
\hline Clavien-Dindo score 2-5 & $\begin{array}{l}\text { ECOG PS: The Eastern Cooperative Oncology Group Performance Score, ASA: American } \\
\text { Society of Anesthesiologists, SD: Standard deviation }\end{array}$ \\
\hline
\end{tabular}

\begin{tabular}{|c|c|c|c|}
\hline & $\begin{array}{l}\text { Group } 1 \\
(n=38)\end{array}$ & $\begin{array}{l}\text { Group } 2 \\
(n=264)\end{array}$ & p-value \\
\hline $\begin{array}{l}\text { Follow-up, median (range) } \\
\text { (months) }\end{array}$ & $\begin{array}{l}85.2 \\
(10.1-160.4)\end{array}$ & $\begin{array}{l}83.7 \\
(13.5-153.9)\end{array}$ & 0.869 \\
\hline Recurrence status, n (\%) & $3(7.9)$ & $9(3.4)$ & $0.181^{*}$ \\
\hline \multicolumn{3}{|l|}{ Patient status, n (\%) } & \\
\hline Alive/recurrence-free & $32(84.2)$ & $\begin{array}{l}226 \\
(85.6)\end{array}$ & \multirow[t]{4}{*}{$0.630^{*}$} \\
\hline Alive/with recurrence & 0 & $5(1.9)$ & \\
\hline Death due to cancer & $3(7.9)$ & $14(5.3)$ & \\
\hline Death due to non-cancer & $3(7.9)$ & $19(7.2)$ & \\
\hline \multicolumn{4}{|l|}{ Overall Survival (\%) } \\
\hline 5-year & 93.6 & 90.0 & \multirow[t]{3}{*}{0.580} \\
\hline 10-year & 76.5 & 71.7 & \\
\hline 15-year & 51.0 & 57.9 & \\
\hline \multicolumn{3}{|l|}{ Cancer Specific Survival (\%) } & \\
\hline 5-year & 96.6 & 95.6 & \multirow[t]{3}{*}{0.948} \\
\hline 10-year & 90.1 & 87.9 & \\
\hline 15-year & 60.1 & 79.9 & \\
\hline \multicolumn{4}{|l|}{ Recurrence-free Survival (\%) } \\
\hline 5-year & 91.2 & 97.7 & \multirow[t]{3}{*}{0.332} \\
\hline 10-year & 91.2 & 94.3 & \\
\hline 15-year & 91.2 & 94.3 & \\
\hline
\end{tabular}

15 -year OS rates were 93.6\%, 76.5\% and 51.0\% in group 1 and $90.0 \%, 71.7 \%$ and $57.9 \%$ in group 2 , respectively ( $\mathrm{p}=0.580$, by logrank test, Figure 1A). CSS did not vary, with 96.6\%, 90.1\% and $60.1 \%$ for $5-, 10-$ and 15 -year CSS rates for PSM patients compared to $95.6 \%, 87.9 \%$ and $79.9 \%$ for those with NSM, respectively ( $p=0.948$, by logrank test, Figure $1 B)$. Further, $15-$ year RFS was $91.2 \%$ in group 1 and $94.3 \%$ in group $2(p=0.332$, by logrank test, Figure 1C).

Based on a multivariate Cox regression analysis, Charlson Comorbidity index (CCl) (HR: 1.343, 95\% Cl: 1.163-1.551, $\mathrm{p}<0.001)$ and high tumour stage (HR: $3.886,95 \% \mathrm{Cl}: 1.576-$ 9.580, $p=0.003$ ) were independently predictive of OS (Table 3 ).
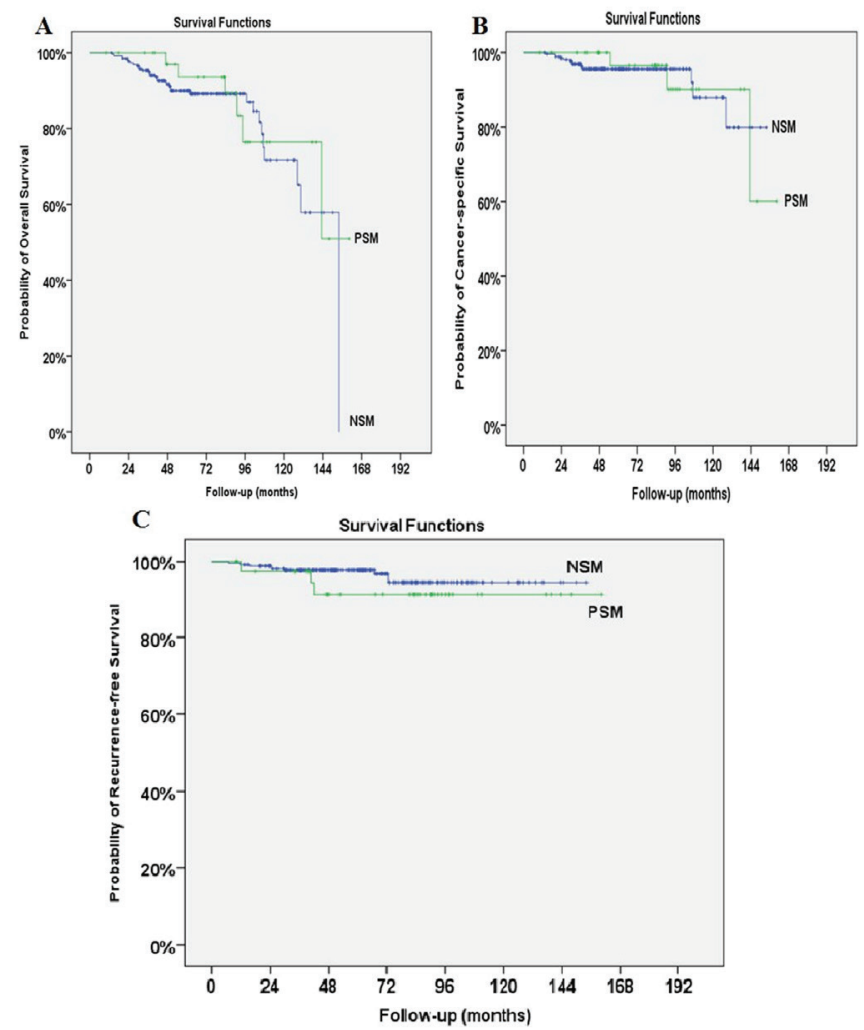

Figure 1. (A) Kaplan-Meier curve for overall survival according to surgical margin status. The $p$ value of the logrank method was 0.580 and the chisquare value was 0.306 . The estimated life expectancy was 137.1 months in group 1 and 129.2 months in group 2 ( $p=0.580)$, (B) Kaplan-Meier curve for cancer-specific survival according to surgical margin status. The $p$ value of the logrank method was 0.948 and the chi-square value was 0.004 . The estimated cancer-free life expectancy was 147.1 months in group 1 and 142.6 months in group 2 ( $p=0.948),(C)$ Kaplan-Meier curve for recurrence-free survival according to surgical margin status. The $p$ value of the logrank method was 0.332 and the chi-square value was 0.942 . The estimated recurrence-free life expectancy was 149.1 months in group 1 and 147.9 months in group 2 $(\mathrm{p}=0.332)$

NSM: Negative surgical margin; PSM: Positive surgical margin

We also observed that CSS was independently decreased with mid-renal tumours (HR: $4.157,95 \% \mathrm{Cl}: 1.478-11.692, \mathrm{p}=0.007$ ), high tumour stage (HR: $6.274,95 \% \mathrm{Cl}: 1.381-28.494, p=0.017$ ) and recurrence of disease (HR: 5.038, 95\% Cl: 1.327-19.131, $\mathrm{p}=0.018$ ) (Table 4). In addition, high pathological T (pT) stage (HR: 32.956, 95\% Cl: 7.749-140.170, $p<0.001$ ) and low C-index value (HR: $0.352,95 \% \mathrm{Cl}: 0.132-0.939, p=0.045$ ) were predictive factors influencing RFS.

\section{Discussion}

Nephron-sparing approaches are focused solely on the removal of renal mass to optimise renal function. In this way, chronic kidney and cardiovascular diseases that may develop in the postoperative period have been prevented, thereby increasing the 


\begin{tabular}{|c|c|c|c|c|c|c|c|c|c|c|}
\hline \multirow[b]{3}{*}{ Age } & \multicolumn{5}{|c|}{ Univariate model } & \multicolumn{5}{|c|}{ Multivariate model ${ }^{*}$} \\
\hline & \multicolumn{4}{|c|}{ HR $(95 \% \mathrm{CI})$} & \multirow{2}{*}{$\begin{array}{l}\mathbf{p} \\
0.002\end{array}$} & \multicolumn{4}{|c|}{ HR $(95 \% \mathrm{Cl})$} & \multirow[t]{2}{*}{ p } \\
\hline & 1.052 & 1.019 & - & 1.085 & & & & & & \\
\hline Gender (ref: male) & 0.646 & 0.323 & - & 1.290 & 0.216 & & & & & \\
\hline Initial Symptom (ref: incidentally) & 0.912 & 0.525 & - & 1.586 & 0.745 & & & & & \\
\hline BMI & 1.020 & 0.943 & - & 1.103 & 0.619 & & & & & \\
\hline $\mathrm{CCl}$ & 1.356 & 1.172 & - & 1.569 & $<0.001$ & 1.343 & 1.163 & - & 1.551 & $<0.001$ \\
\hline ECOG PS & 1.517 & 0.984 & - & 2.340 & 0.059 & & & & & \\
\hline ASA Score & 2.104 & 1.319 & - & 3.355 & 0.002 & & & & & \\
\hline Tumor size & 1.017 & 0.999 & - & 1.035 & 0.065 & & & & & \\
\hline Mid-renal tumors & 1.758 & 0.923 & - & 3.348 & 0.086 & & & & & \\
\hline PADUA score & 1.029 & 0.857 & - & 1.235 & 0.759 & & & & & \\
\hline RENAL nephrometry score & 0.975 & 0.798 & - & 1.191 & 0.802 & & & & & \\
\hline C-Index & 1.039 & 0.678 & - & 1.590 & 0.862 & & & & & \\
\hline Surgery technique (ref: open) & 0.517 & 0.226 & - & 1.181 & 0.117 & & & & & \\
\hline Positive surgical margin & 0.778 & 0.319 & - & 1.899 & 0.581 & & & & & \\
\hline RCC subtype & 0.792 & 0.450 & - & 1.397 & 0.421 & & & & & \\
\hline pT stage & 1.463 & 1.034 & - & 2.071 & 0.032 & & & & & \\
\hline High pT stage (ref: stage I) & 3.833 & 1.450 & - & 10.132 & 0.007 & & & & & \\
\hline Nuclear Grade & 0.905 & 0.646 & - & 1.268 & 0.560 & & & & & \\
\hline Tumor stage & 2.138 & 1.339 & - & 3.413 & 0.001 & & & & & \\
\hline High tumor stage (ref: stage I) & 4.172 & 1.697 & - & 10.255 & 0.002 & 3.886 & 1.576 & - & 9.580 & 0.003 \\
\hline Clavien-Dindo score & 0.888 & 0.418 & - & 1.886 & 0.757 & & & & & \\
\hline Recurrence & 2.616 & 0.912 & - & 7.502 & 0.074 & & & & & \\
\hline
\end{tabular}

OS $(10,11)$. The clinical and oncological effects of PSM after PN have been addressed. In recent years, studies which showed that PSM does not have oncologically worse effects have increased. Our aim was to reveal the clinical and oncological effects of PSM in our clinic with long follow-up data.

Previously, a healthy tissue margin of around $1 \mathrm{~cm}$ was proposed to get rid of cancer $(12,13)$. However, some reports have indicated that the width of this healthy tissue margin does not affect oncological outcomes (13). Moreover, broader excision limits have been correlated with increased loss of normal parenchymal tissue volume and reduced renal function (14). In addition, some reports showed that simple enucleation and enucleo-resection techniques have equivalent oncological results compared to standard resection (15-17). Therefore, the absence of microscopic malignant tissue at the resection margin is known as NSM.

The occurrence of PSM reported in the literature ranges from $0 \%$ to $15 \%$, regardless of the $\mathrm{PN}$ technique (18). The rate in our study (12.6\%) did not vary from these series. Shah et al. (4) stated that PSM was irrelevant to tumour size, histology, localisation, nuclear grade, tumour stage or laterality. Conversely, another study identified blood loss, tumour grade and tumour stage as predictors of PSM (19). Ani et al. (20) indicated that there was an important correlation between stage and fat invasion and PSM. In the present analysis, we determined that the RENAL nephrometry score and $\mathrm{C}$-index value were significant predictive factors for PSM. Most of literature studies report that PSM does not increase recurrence $(21,22)$. Similarly, we also found that the prevalence of recurrence in PSM patients was higher, but not statistically significant. Some studies have reported that PSM is a poor prognostic factor for recurrence $(3,7,23)$. Khalifeh et al. (3) also stated that they did not find a significant risk factor for PSM in the analysis of factors such as tumour size, grade, stage and surgeon's learning curve. However, they concluded that PSM is associated with local recurrence and metastasis and reported a 3-year cancer-free recurrence rate of $47.0 \%$ and a 


\begin{tabular}{|c|c|c|c|c|c|c|c|c|c|c|}
\hline \multirow[b]{3}{*}{ Age } & \multicolumn{5}{|c|}{ Univariate model } & \multicolumn{5}{|c|}{ Multivariate model ${ }^{*}$} \\
\hline & \multicolumn{4}{|c|}{ HR $(95 \% \mathrm{Cl})$} & \multirow{2}{*}{$\begin{array}{l}\mathbf{p} \\
0.548\end{array}$} & \multicolumn{4}{|c|}{ HR $(95 \% \mathrm{Cl})$} & \multirow[t]{2}{*}{$\mathbf{p}$} \\
\hline & 0.988 & 0.950 & - & 1.028 & & & & & & \\
\hline Gender (ref: male) & 0.452 & 0.146 & - & 1.398 & 0.168 & & & & & \\
\hline Initial Symptom (ref: incidentally) & 0.590 & 0.217 & - & 1.600 & 0.300 & & & & & \\
\hline $\mathrm{BMI}$ & 1.041 & 0.926 & - & 1.171 & 0.498 & & & & & \\
\hline $\mathrm{CCl}$ & 1.109 & 0.867 & - & 1.417 & 0.410 & & & & & \\
\hline ECOG PS & 1.106 & 0.551 & - & 2.219 & 0.778 & & & & & \\
\hline ASA Score & 1.171 & 0.366 & - & 3.750 & 0.790 & & & & & \\
\hline Tumor size & 1.020 & 0.995 & - & 1.046 & 0.115 & & & & & \\
\hline Mid-renal tumors & 3.313 & 1.212 & - & 9.058 & 0.020 & 4.157 & 1.478 & - & 11.692 & 0.007 \\
\hline PADUA score & 1.306 & 1.013 & - & 1.683 & 0.030 & & & & & \\
\hline RENAL nephrometry score & 1.239 & 0.939 & - & 1.636 & 0.130 & & & & & \\
\hline C-Index & 0.352 & 0.132 & - & 0.939 & 0.037 & & & & & \\
\hline Surgery technique (ref: open) & 0.498 & 0.142 & - & 1.747 & 0.276 & & & & & \\
\hline Operation time & 0.982 & 0.962 & - & 1.001 & 0.065 & & & & & \\
\hline Positive surgical margin & 0.958 & 0.264 & - & 3.472 & 0.948 & & & & & \\
\hline RCC subtype & 1.055 & 0.518 & - & 2.150 & 0.883 & & & & & \\
\hline pT stage & 1.942 & 1.294 & - & 2.915 & 0.001 & & & & & \\
\hline High pT stage (ref: stage I) & 5.169 & 1.395 & - & 19.154 & 0.014 & & & & & \\
\hline Nuclear Grade & 0.961 & 0.594 & - & 1.557 & 0.873 & & & & & \\
\hline Tumor stage & 2.685 & 1.399 & - & 5.156 & 0.003 & & & & & \\
\hline High tumor stage (ref: stage I) & 4.499 & 1.234 & - & 16.397 & 0.023 & 6.274 & 1.381 & - & 28.494 & 0.017 \\
\hline Clavien-Dindo score & 1.566 & 0.938 & - & 2.613 & 0.086 & & & & & \\
\hline Recurrence & 6.709 & 2.108 & - & 21.357 & 0.001 & 5.038 & 1.327 & - & 19.131 & 0.018 \\
\hline
\end{tabular}

3-year metastasis-free survival rate of $63.0 \%$ in patients with PSM (3). Similarly, Bensalah et al. (6) reported that PSM had a higher risk of recurrence and a lower RFS in a study of 775 patients, of which 111 were patients with PSM. No difference was observed between the two groups on OS, CSS and RFS in the current study.

The uncertainty about PSM remains, as most studies have heterogeneous masses, fewer patients or shorter follow-up periods. In this study, the C-index, RENAL nephrometry and Padua scores, which define the tumour complexity, were analysed to determine the sample homogeneity. Fuhrman nuclear grade, tumour stage according to TNM staging, necrosis and capsule invasion were not statistically different between the groups. The C-index value, which predicted that patients with PSM had more complex tumours, was lower in group 1. We also found that $\mathrm{C}$-index value predicting RFS was an independent risk factor in multivariate model analysis between groups that were homogenous in terms of tumour characteristics. Another study showed that the high RENAL nephrometry score was associated with an increased risk of residual disease (4). In addition, it was also reported that the risk of relapse in PSM patients was correlated with an increased pT stage or Fuhrman grade $(4,6)$. In the present analysis, the advanced pT stage had a worse effect on CSS and OS in univariate analyses. On the other hand, Yossepowitch et al. (5) stated that intraoperative tumor control would be more difficult due to a decrease in tumor size and it would have a higher PSM rate. Furthermore, in a retrospective review of 1048 open PN patients by Patard et al. (24), tumour size did not affect the incidence of PSM.

Some studies have documented that renal ischaemia caused by clamping of the renal artery might destroy cells with rapid metabolic cycles, such as cancer cells (5). We also observed similar 
findings. Non-ischaemic procedures were mostly performed in patients with PSM in the current cohort. In addition to tumour foci that are extirpated with renal ischaemia, we thought that a decrease in visual quality due to bleeding in non-ischaemic procedures may also have an impact on this issue. Additionally, residual tumour cells have also been documented to have been damaged by thermal effects, such as cauterisation after renal mass resection (5). The residual tumour rate was stated to be $7 \%-39 \%$ in patients with PSM $(6,25)$. In fact, this high incidence may also cause concern about the prognosis of patients. However, as in the current study, PSM was not associated with poor prognosis $(5,21,22)$. Certain studies have shown a higher prevalence of high-grade RCC in patients with PSM $(4,6,25)$. They also argue that a reduction in recurrence-free and metastasisfree survival in patients with PSM can be prevented through safer and wider resection, particularly in high-risk patients.

The treatment of PSM patients is also uncertain. It is controversial whether follow-up, total nephrectomy or re-resection should be done in patients with recurrent tumours. Indeed, Sundaram et al. (25) reported a study involving 29 PSM patients. No tumour was detected in any of the 8 patients who underwent complementary total nephrectomy; only two of the 21 patients who underwent re-resection were confirmed to have tumours (25). Retrospectively, Raz et al. (26) analysed 114 patients who underwent PN, 15\% of whom had PSM. Approximately half of the patients with PSM underwent radical nephrectomy. Only 11.7\% of these patients had residual tumour tissue. Complementary surgery for patients with PSM showed that it was overtreatment (26). Similarly, Yossepowitch et al. (5) reported that PSM was not a negative factor for local or metastatic progression in a cohort of 1344 patients for at 5 and 10 years of follow-up. In another study with a long follow-up period, it was confirmed that PSM did not pose a risk for local recurrence or distant metastasis (27). Moreover, active surveillance was reported to be more preferred than complementary nephrectomy or resection in the management of PSM patients (28). In our study, which also included long-term follow-up results, we found that PSM had no influence on OS, CSS or RFS. Reasonable options such as complementary radical nephrectomy, recurrent $\mathrm{PN}$, energy ablation of the tumour bed or active monitoring for each patient should be applied to evaluate the patient and tumour characteristics (29).

We investigated the significance of PSM in RFS, CSS and OS analyses. Various literature studies have compared OS times of patients with PSM. Maurice et al. (30) determined that PSM had a significant hazard ratio of 1.35 for overall mortality. They also stated that PSM patients had older and higher $\mathrm{CCl}$ in univariate analyses and concluded that $\mathrm{CCl}$ and $\mathrm{pT}$ stage were associated with both PSM and OS in multivariate analyses. In comparison to our study, they emphasised that PSM was associated with poorer OS. In the multivariate analysis of the factors affecting the OS, we found that $\mathrm{CCl}$ and high $\mathrm{pT}$ stage were independent predictors. On the other hand, PSM was not effective on OS. In addition, Marszalek et al. (28) stated that PSM had no effect on disease-free survival and OS. Similarly, Bensalah et al. (6) found that PSM patients had no detrimental effect on progressionfree survival and CSS. Moreover, there was a shorter time to recurrence in these patients than in NSM patients (21.3 vs 27.7 months, respectively; $p=0.004$ ), but there were no statistically significant differences in CSS. In the current study, we found that the independent factors influencing CSS were mid-renal localisation, high-stage tumour and recurrence.

\section{Study Limitations}

In addition to the retrospective design, this study had some limitations. There was no standard for tumour resection technique among surgeons as technological advances continued during the study period. Although the groups were identical in terms of tumour characteristics and demographic features, the absence of a complete matched pair was another limitation of our study. Propensity score matching helps to reduce selection bias and confounding. However, this study, which has longer follow-up times relative to many studies in the literature, contains an overview of data collected from the follow-up of the mid- to long-term oncological outcomes of PSM patients. In addition, one of the strengths of our study is that all cases belong to a single centre.

\section{Conclusion}

Although RCCs have heterogeneous characteristics, the probability of recurrence after PN is very low, as in groups with homogeneous tumour characteristics in our study. High RENAL nephrometry score and low $\mathrm{C}$-index value suggest an increased risk of tumour complexity as an independent risk factor for predicting PSM. The C-index is also a predictor that affects RFS. Tumour stage is an independent risk factor that decreases both CSS and OS. Other predictive factors include CCI for OS, mid-renal localisation and recurrence for CSS and pT stage for RFS. Based on our findings, PSM is not a factor that has a detrimental effect on recurrence or survival, even though it is not a good pathology result after surgery. We therefore agree that an active and careful clinical monitoring could be the most effective method for patients with PSM.

\section{Ethics}

Ethics Committee Approval: Following the approval by the local ethics committee (approval date: 20.01.2020, decision number: 80/08).

Informed Consent: Retrospective study. 
Peer-review: Externally and internally peer-reviewed.

\section{Authorship Contributions}

Concept: M.Ç.Ç., N.K., S.S., L.S., Design: M.Ç.Ç., N.K., S.S., H.T., H.E., Data Collection or Processing: M.Ç.Ç., N.K., A.K., S.S., F.S., O.R.K., H.E., Analysis or Interpretation: M.Ç.Ç., N.K., S.S., O.R.K., L.S., H.T., Literature Search: M.Ç.Ç., A.K., F.S., O.R.K., L.S., H.T., H.E., Writing: M.Ç.Ç., N.K., A.K., F.S., L.S., H.T.

Conflict of Interest: No conflict of interest was declared by the authors.

Financial Disclosure: The authors declared that this study received no financial support.

\section{References}

1. Van Poppel H, Da Pozzo L, Albrecht W, Matveev V, Bono A, Borkowski A, Colombel M, Klotz L, Skinner E, Keane T, Marreaud S, Collette S, Sylvester R. A prospective, randomised EORTC intergroup phase 3 study comparing the oncologic outcome of elective nephronsparing surgery and radical nephrectomy for low-stage renal cell carcinoma. Eur Urol 2011;59:543-552.

2. Scosyrev E, Messing EM, Sylvester R, Campbell S, Van Poppel H. Renal function after nephron-sparing surgery versus radical nephrectomy: results from EORTC randomized trial 30904. Eur Urol 2014;65:372-377.

3. Khalifeh A, Kaouk JH, Bhayani S, Rogers C, Stifelman M, Tanagho YS, Kumar R, Gorin MA, Sivarajan G, Samarasekera D, Allaf ME. Positive surgical margins in robot-assisted partial nephrectomy: a multi-institutional analysis of oncologic outcomes (leave no tumor behind). J Urol 2013;190:1674-1679.

4. Shah PH, Moreira DM, Okhunov Z, Patel VR, Chopra S, Razmaria AA, Alom M, George AK, Yaskiv 0, Schwartz MJ, Desai M, Vira MA, Richstone L, Landman J, Shalhav AL, Gill I, Kavoussi LR. Positive surgical margins increase risk of recurrence after partial nephrectomy for high risk renal tumors. J Urol 2016;196:327-334.

5. Yossepowitch O, Thompson RH, Leibovich BC, Eggener SE, Pettus JA, Kwon ED, Herr HW, Blute ML, Russo P. Positive surgical margins at partial nephrectomy: predictors and oncological outcomes. J Urol 2008;179:2158163.

6. Bensalah K, Pantuck AJ, Rioux-Leclercq N, Thuret R, Montorsi F, Karakiewicz $\mathrm{Pl}$, Mottet N, Zini L, Bertini R, Salomon L, Villers A, Soulie M, Bellec L, Rischmann P, De la Taille A, Avakian R, Crepel M, Ferriere JM, Bernhard JC, Dujardin T, Pouliot F, Rigaud J, Pfister C, Albouy B, Guy L, Joniau S, van Poppel H, Lebret T, Culty T, Saint F, Zisman A, Raz O, Lang H, Spie R, Wille $A$, Roigas J, Aguilera A, Rambeaud B, Martinez Piñeiro L, Nativ 0, Farfara R, Richard F, Roupret M, Doehn C, Bastian PJ, Muller SC, Tostain J, Belldegrun AS, Patard JJ. Positive surgical margin appears to have negligible impact on survival of renal cell carcinomas treated by nephron-sparing surgery. Eur Urol 2010;57:466-471.

7. Kwon EO, Carver BS, Snyder ME, Russo P. Impact of positive surgical margins in patients undergoing partial nephrectomy for renal cortical tumours. BJU Int 2007;99:286-289.

8. Dindo D, Demartines N, Clavien PA. Classification of surgical complications: a new proposal with evaluation in a cohort of 6336 patients and results of a survey. Ann Surg 2004;240:205-213.

9. Fuhrman SA, Lasky LC, Limas C. Prognostic significance of morphologic parameters in renal cell carcinoma. Am J Surg Pathol 1982;6:655-663.

10. Weight $\mathrm{CJ}$, Larson BT, Fergany AF, Gao T, Lane BR, Campbell SC, Kaouk JH, Klein EA, Novick AC. Nephrectomy induced chronic renal insufficiency is associated with increased risk of cardiovascular death and death from any cause in patients with localized cT1b renal masses. J Urol 2010;183:13171323.

11. Go AS, Chertow GM, Fan D, McCulloch CE, Hsu CY. Chronic kidney disease and the risks of death, cardiovascular events, and hospitalization. N Engl J Med 2004;351:1296-1305.

12. Russo P. Renal cell carcinoma: presentation, staging, and surgical treatment. Semin Oncol 2000;27:160-176.

13. Sutherland SE, Resnick MI, Maclennan GT, Goldman HB. Does the size of the surgical margin in partial nephrectomy for renal cell cancer really matter? J Urol 2002;167:61-64.

14. Lane BR, Russo P, Uzzo RG, Hernandez AV, Boorjian SA, Thompson RH, Fergany AF, Love TE, Campbell SC. Comparison of cold and warm ischemia during partial nephrectomy in 660 solitary kidneys reveals predominant role of nonmodifiable factors in determining ultimate renal function. J Urol $2011 ; 185: 421-427$

15. Puppo $P$, Introini $C$, Calvi $P$, Naselli A. Long term results of excision of small renal cancer surrounded by a minimal layer of grossly normal parenchyma: review of 94 cases. Eur Urol 2004:46:477-481.

16. Schiavina R, Serni $S$, Mari $A$, Antonelli $A$, Bertolo R, Bianchi G, Brunocilla $E_{\text {, }}$ Borghesi M, Carini M, Longo N, Martorana G, Mirone V, Morgia G, Porpiglia F, Rocco B, Rovereto B, Simeone C, Sodano M, Terrone C, Ficarra V, Minervini A. A prospective, multicenter evaluation of predictive factors for positive surgical margins after nephron-sparing surgery for renal cell carcinoma: the RECORd1 Italian Project. Clin Genitourin Cancer 2015;13:165-170.

17. Minervini A, Ficarra V, Rocco F, Antonelli A, Bertini R, Carmignani G, Cosciani Cunico S, Fontana D, Longo N, Martorana G, Mirone V, Morgia G, Novara G, Roscigno M, Schiavina R, Serni S, Simeone C, Simonato A, Siracusano S, Volpe A, Zattoni F, Zucchi A, Carini M. SATURN Project-LUNA Foundation. Simple enucleation is equivalent to traditional partial nephrectomy for renal cell carcinoma: results of a nonrandomized, retrospective, comparative study. J Urol 2011;185:1604-1610.

18. Minervini A, Campi $R$, Sessa $F$, Derweesh I, Kaouk JH, Mari $A$, Rha $\mathrm{KH}$ Sessa M, Volpe A, Carini M, Uzzo RG. Positive surgical margins and local recurrence after simple enucleation and standard partial nephrectomy for malignant renal tumors: systematic review of the literature and metaanalysis of prevalence. Minerva Urol Nefrol 2017;69:523-538.

19. Bansal RK, Tanguay S, Finelli A, Lacombe L, Black PC, Kawakami J, Drachenberg D, Pautler S, Saarela O, Liu Z, Jewett MAS, Kapoor A. Positive surgical margins during partial nephrectomy for renal cell carcinoma: Results from Canadian Kidney Cancer information system (CKCis) collaborative. Can Urol Assoc J 2017;11:182-187.

20 . Ani I, Finelli A, Alibhai SM, Timilshina N, Fleshner N, Abouassaly R. Prevalence and impact on survival of positive surgical margins in partial nephrectomy for renal cell carcinoma: a population-based study. BJU Int 2013;111:E300E305.

21. Fergany $A F$, Hafez $K S$, Novick $A C$. Long-term results of nephron sparing surgery for localized renal cell carcinoma:10-year followup. J Urol 2000;163:442-445.

22. Borghesi $M$, Brunocilla $E$, Schiavina $R$, Martorana G. Positive surgical margins after nephron-sparing surgery for renal cell carcinoma: incidence, clinical impact, and management. Clin Genitourin Cancer 2013;11:5-9.

23. Bernhard JC, Pantuck $A J$, Wallerand $H$, Crepel $M$, Ferrière JM, Bellec $L$, Maurice-Tison S, Robert G, Albouy B, Pasticier G, Soulie M, Lopes D, Lacroix B, Bensalah K, Pfister C, Thuret R, Tostain J, De La Taille A, Salomon L, Abbou C, Colombel $M$, Belldegrun AS, Patard JJ. Predictive factors for ipsilateral recurrence after nephron-sparing surgery in renal cell carcinoma. Eur Urol 2010;57:1080-1086

24. Patard JJ, Pantuck AJ, Crepel M, Lam JS, Bellec L, Albouy B, Lopes D, Bernhard JC, Guillé F, Lacroix B, De La Taille A, Salomon L, Pfister C, Soulié M, Tostain J, Ferriere JM, Abbou CC, Colombel M, Belldegrun AS. Morbidity 
and clinical outcome of nephronsparing surgery in relation to tumour size and indication. Eur Urol 2007;52:148-154.

25. Sundaram V, Figenshau RS, Roytman TM, Kibel AS, Grubb RL 3rd, Bullock $A$, Benway BM, Bhayani SB. Positive margin during partial nephrectomy: does cancer remain in the renal remnant? Urology 2011;77:1400-1403.

26. Raz O, Mendlovic $S$, Shilo Y, Leibovici D, Sandbank J, Lindner A, Zisman A. Positive surgical margins with renal cell carcinoma have a limited influence on long-term oncological outcomes of nephron sparing surgery. Urology 2010;75:277-280.

27. Lopez-Costea MA, Fumadó L, Lorente D, Riera L, Miranda EF. Positive margins after nephronsparing surgery for renal cell carcinoma: long-term follow-up of patients on active surveillance. BJU Int 2010;106:645-648.
28. Marszalek $M$, Carini $M$, Chlosta $P$, Jeschke $K$, Kirkali $Z$, Knüchel $R$, Madersbacher S, Patard JJ, Van Poppel H. Positive surgical margins after nephron-sparing surgery. Eur Urol 2012;61:757-763.

29. Rassweiler J, Rassweiler MC, Kenngott $H$, Frede $T$, Michel MS, Alken $P$, Clayman R. The past, present and future of minimally invasive therapy in urology: a review and speculative outlook. Minim Invasive Ther Allied Technol 2013;22:200-209.

30. Maurice MJ, Zhu H, Kim SP, Abouassaly R. Reexamining the association between positive surgical margins and survival after partial nephrectomy in a large American cohort. J Endourol 2016;30:698-703. 